\title{
The Characteristics of Cassava Var. Gajah (Manihot esculenta $C$ ) Derivative Products as a Thickening Agent in the Manufacturing of Tamarind (Tamrindicus indica) Paste
}

\author{
Sulistyo Prabowo*, Maulida Rachmawati, Yulian Andriyani, Agustu Sholeh \\ Pujokaroni, Kintan Katrin, and Nurmita Sari \\ Department of agricultural product technology, Mulawarman University, Indonesia, 75119 \\ *Corresponding author.: sprabowo@faperta.unmul.ac.id

\begin{abstract}
Cassava var. Gajah (Manihot esculenta $C$ ) is a typical crop of East Kalimantan which has potential to be developed into a carbohydrate-based agricultural industry commodity. However, the cassava var. Gajah has not been used optimally, and limited research has been done. We conducted this research to utilize cassava derivatives products namely cassava starch and cassava flour as a natural thickening agent (NTA) in tamarind pasta making. The characteristics of paste obtained were identified: its viscosity, water content, ash content, $\mathrm{pH}$, and solubility . This study used a completely randomized design with three replications. With thickening agent concentrations is 1,3 , and $5 \%$ (w/v). The results showed that adding a $5 \%$ cassava starch had the best effects on the viscosity, water content, and pH of 8,586 Pa.s, 74\%, and $2.46 \%$, respectively. Cassava flour $5 \%$ gave the highest starch content which is $3.05 \%$. The addition of $3 \%$ cassava starch resulted in ash content of $1.66 \%$. Cassava flour $5 \%$ gave the highest value in the solubility test, $19.33 \%$, with the solubility speed being slower with the addition of a thickening agent. This study suggests that the derivative products of cassava could be used as an alternative natural thickener in the manufacture of tamarind paste.
\end{abstract}

Keywords: Cassava var. Gajah, tamarind, tamarind paste, viscosity.

\section{INTRODUCTION}

Cassava var. Gajah (Manihot esculenta $C$ ) is a superior plant typical of East Kalimantan which its use continues to be developed [1]. This plant can produce cassava tubers up to $50 \mathrm{~kg}$ per tree, ten times more than other types of cassava. The high production rate of Cassava var. Gajah has excellent potential to be developed into a carbohydrate-based agricultural, industrial commodity which can be in the form of flour and starch as intermediate products.

Tamarind (Tamarindus indica) is a popular plant that is easy to find in tropical areas, including Indonesia. Tamarind is rich in antioxidants, protein, carbohydrates, minerals, iron, and vitamin A [2]. The antioxidant compounds function as a preventive for heart disease, lower cholesterol, and increase the body's immune system [3]. Unfortunately, the benefits provided by
Tamarind still are not elaborate. The use of tamarind is still limited and not practical for some reasons. The shelf life is relatively low and the appearance does not attract attention are some reasons to be mentioned.

Processing is one way to improve the quality of a food ingredient [4]. With the selection of the proper processing system, the product obtained from Tamarind is expected to be more acceptable by the community. Processing tamarind into tamarind paste is expected to be a solution as it is easy to use, increases shelf life, and is easy to store.

Pasta is a semi-liquid colloid used to manufacture food or consumed directly as a spread [5]. In general, pasta is defined as a semi-finished processed form using raw materials such as fruit and other processed products in the form of porridge to which food additives have been added.

As far as our concern, no research on Cassava var. Gajah for a thickening agent in the manufacture of 
tamarind paste has been found. Thus, the purpose of this study was to determine the effect of adding cassava flour and starch as a thickening agent in the manufacture of acid paste on viscosity, solubility, speed of dissolution, acidity, color, water content, ash content, starch content, and total acid titrated.

\section{MATERIAL AND METHODS}

\subsection{Materials}

The cassava used in this study was harvested at the age of 8 months and obtained from the Field Laboratory of the Faculty of Agriculture in Karang Tunggal Village, Tenggarong Seberang District, Kutai Kartanegara, East Kalimantan. The tamarind fruit was obtained from local trader and originally came from East Java.

\subsection{Methods}

\subsubsection{Cassava flour preparation}

Cassava at $800 \mathrm{~g}$ was peeled and washed with running water then sliced using a chopper machine approximately 1-2 mm thick. Chopped cassava then dried for 24 hours using oven at a temperature of $60^{\circ} \mathrm{C}$. After dried, the baked cassava was ground using a grinder and then sieved (80 mesh).

\subsubsection{Cassava Starch Preparation}

Cassava was peeled and washed thoroughly with running water, grated using a chopper machine and blended with a 1:3 addition of fresh water. The cassava pulp is then squeezed and let the water extract settle for 4 hours. The starch precipitate was collected and dried in an oven at $70{ }^{\circ} \mathrm{C}$ for 20 hours. After drying, the cassava chips were ground using a grinder and then sieved (80 mesh). The starch powder was collected and stored in a glass case before further use.

\subsubsection{Tamarind Puree Preparation}

Tamarind flesh was sorted and separated from the seeds. Puree is processed by crushing the flesh of the tamarind fruit using a blender by adding water as much as 3 parts of the weight of the tamarind. The tamarind extract is then filtered to separate the fiber and the crude material.

\subsubsection{Tamarind Paste Preparation}

The process of tamarind paste making was carried out in several stages, namely preparation of ingredients, mixing of ingredients, and cooking. Firstly, cassava flour and starch were weighing according to their respective concentrations of $1 \%, 2 \%, 3 \% \mathrm{w} / \mathrm{w}$, and $100 \mathrm{~g}$ of tamarind puree. Tamarind puree was put in the pot, added a thickener and then cooked in the hotplate at low heat until it reaches a temperature of $60^{\circ} \mathrm{C}$ and maintained for 2 minutes. Cooked tamarind paste was removed and transferred to sterilized glass jars.

\subsubsection{Analysis Method}

The viscosity test was determined using [6]. The solubility test used the Locksuwan method [7]. The degree of acidity was tested using the method of the National Standardization Agency (SNI 066989.112004). Sample color testing using CS-10 Colorimeter, CHN Spec Technology, China. The water, ash, starch content, and total titrated acid were determined using the AOAC method [8].

\section{RESULTS AND DISCUSSION}

The chemical composition of cassava flour and cassava starch are shows in Table 1. Cassava flour is made from peeled cassava so it still contains high fiber and lower carbohydrates than starch flour. As a NTA from cassava, the starch content plays an important role as it affects the viscosity of the paste due to the gelatinization process. Gelatinization is a gel formation process that begins with the swelling of starch granules due to water absorption during heating. Starch granules are insoluble in cold water but expand in the presence of hot water.

The moisture content of tamarind paste is an essential factor in determining the level of pasta product viscosity. Paste product is semi-solid in nature. The effect of adding NTA from cassava flour and cassava starch to the water content were resumed in Table 2 . The lowest percentage of the water content of tamarind paste was obtained with the addition of $5 \%$ cassava starch, which was $75.73 \%$. As

Table 1. Chemical composition of NTA from Cassava var. Gajah

\begin{tabular}{|l|c|c|}
\hline \multirow{2}{*}{ Composition (\%) } & \multicolumn{2}{|c|}{ NTA } \\
\cline { 2 - 3 } & C. flour & C. starch \\
\hline Water content & 6,77 & 10,13 \\
\hline Ash content & 2,05 & 0,43 \\
\hline Protein & 0,53 & 0,18 \\
\hline Starch content & 18,34 & 23,45 \\
\hline
\end{tabular}

the NTA increase, the water content of the paste will decrease. The trends are same for both cassava starch and cassava flour. During the gelatinization process amylopectin will bind the free water content so the water is reduced in the product [9]. 
Table 2. The water content (\%) of tamarind paste with the addition of a NTA

\begin{tabular}{|c|c|c|}
\hline \multirow{2}{*}{$\begin{array}{c}\text { Concentration } \\
\%)\end{array}$} & \multicolumn{2}{|c|}{ NTA } \\
\cline { 2 - 3 } & C. flour & C. starch \\
\hline 0 & $82,617 \pm 0,24 \mathrm{a}$ & $82,617 \pm 0,25 \mathrm{a}$ \\
\hline 1 & $81,585 \pm 0,47 \mathrm{~b}$ & $80,448 \pm 0,68 \mathrm{~b}$ \\
\hline 3 & $78,701 \pm 1,15 \mathrm{c}$ & $78,864 \pm 0,50 \mathrm{c}$ \\
\hline 5 & $75,731 \pm 1,36 \mathrm{~d}$ & $76,860 \pm 0,50 \mathrm{~d}$ \\
\hline
\end{tabular}

The effect of NTA addition to the ash content of tamarind paste shows in Table 3 . The addition of cassava starch and cassava flour gave different results. For example, adding 1\%, cassava starch reduced the ash content by $1.98 \%$ from $2.049 \%$ and continued to decrease to $1.659 \%$ at a concentration of $3 \%$, then increased to $1.791 \%$ when given cassava starch with a concentration of $5 \%$.

The application of cassava flour to Tamarind paste at concentration $1 \%$ gave a decrease in the ash content from $2.049 \%$ to $1.783 \%$, then increased to $2.312 \%$ when given cassava flour with a concentration of $3 \%$, then decreased to $2.122 \%$ at a concentration of $5 \%$. In general, the ash content in pasta using cassava flour has a higher than in cassava starch. This can be understood because in the manufacture of cassava flour still contains a lot of fiber and other mineral ingredients, while in the manufacture of tapioca most of the fiber has been lost in the squeezing process [10] [11].

As the addition of NTA increased the starch content of the tamarind paste produced also increased (Table 4). The addition of $5 \%$ thickener gave the highest starch content value, namely $2.246 \%$ for pasta with cassava

Table 3. The ash content (\%) of tamarind paste with the addition of a NTA

\begin{tabular}{|c|c|c|}
\hline \multirow{2}{*}{$\begin{array}{c}\text { Concentration } \\
(\%)\end{array}$} & C. flour & C. starch \\
\cline { 2 - 3 } & $2,049 \pm 0,09 a$ & $2,049 \pm 0,09 a$ \\
\hline 0 & $1,980 a$ & $1,783 \pm 0,16 a$ \\
\hline 3 & $1,659 \pm 0,19 a$ & $2,312 \pm 0,62 a$ \\
\hline 5 & $1,791 \pm 0,28 a$ & $2,122 \pm 0,09 a$ \\
\hline
\end{tabular}

starch thickener and $3.053 \%$ with cassava flour thickener. The decrease in starch content in pasta with cassava starch thickener was due to gelatinization during the processing of the starch contained in the material [9]. While in cassava flour, the percentage of starch content
Table 4. The starch content $(\%)$ of tamarind paste with the addition of a NTA

\begin{tabular}{|c|c|c|}
\hline \multirow{2}{*}{$\begin{array}{c}\text { Concentration } \\
(\%)\end{array}$} & \multicolumn{2}{|c|}{ NTA } \\
\cline { 2 - 3 } & C. flour (\%) & C. starch (\%) \\
\hline 0 & $1,267 \pm 0,85 a$ & $1,267 \pm 0,85 a$ \\
\hline 1 & $1,152 \pm 0,22 a$ & $1,555 \pm 0,37 a$ \\
\hline 3 & $1,670 \pm 0,29 a$ & $1,613 \pm 0,57 a$ \\
\hline 5 & $2,246 \pm 0,37 a$ & $3,053 \pm 0,36 a$ \\
\hline
\end{tabular}

in Tamarind increased because other compounds contained in it also decreased, so that the rate of starch content increased.

Table 5. shows the effect of adding NTA to the titrated acid content of tamarind paste. The process of processing tamarind paste with the addition of cassava starch and cassava flour affects the titrated acid levels in the resulting tamarind paste. The higher the thickener concentration used, the lower the level of titrated acid in the paste. For example, the addition of cassava starch 5\% reduced the titrated acid content with a percentage of $75.731 \%$ from $82.617 \%$. This is because the processing that is carried out uses a lot of water. Therefore, adding a thickening agent will reduce the percentage of titrated acid levels in the paste.

The effect of adding NTA to the viscosity of tamarind paste can be seen in Figure 1. As the NTA increase the viscosity of the tamarind paste also increase. The lowest viscosity value was in the control sample (2.45 Ps.a), and the highest viscosity was in tamarind with the addition of a thickener from cassava starch with a concentration of 5\% (8.58 Ps.a). The increase in the tamarind paste

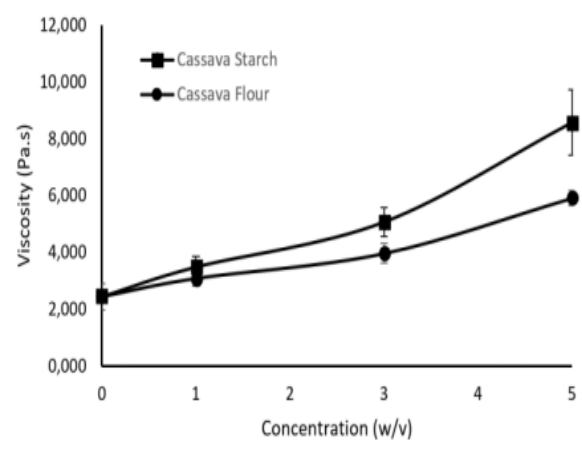

Figure 1. The Viscosity of tamarind paste with the addition of a NTA

viscosity follows the theory where the starch content influences the gelatinization process in the material. The addition of a thickener will increase the starch content, as shown in Table 4. The amylose and amylopectin content in cassava and the processing temperature affect the viscosity [10]. The amylose and amylopectin content in 
cassava is $17 \%$ and $83 \%$, respectively [12]. The gelatinization temperature reaches $52-54^{\circ} \mathrm{C}$; this is what causes the paste product to be thicker.

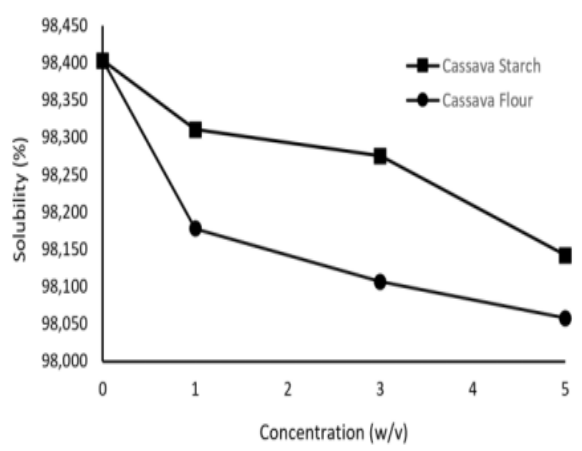

Figure 2. The solubility of tamarind paste with the addition of a NTA

Solubility determines the quality of the tamarind paste produced. The effect of NTA addition on the solubility of tamarind paste can be seen in Figure 2. The solubility of tamarind paste increased compared to the control, but this increase stopped after adding a thickener with a concentration of $1 \%$. At concentrations of 3 and $5 \%$, the addition of a thickening agent, the solubility of tamarind paste did not experience much difference compared to the addition of a $1 \%$ thickener for both cassava starch and cassava flour. The change in solubility occurs because of amylose and amylopectin content in the thickener agent and the gelatinization temperature used in the processing [13]. Alcazar-alay and Mireles reported that there are similarities in the properties of the products produced between products with a thickener from rice flour, corn starch, and tapioca [14].

Table 5. The titrated acid (\%) content of tamarind paste with the addition of a NTA.

\begin{tabular}{|c|l|l|}
\hline \multirow{2}{*}{$\begin{array}{c}\text { Concentration } \\
(\%)\end{array}$} & \multicolumn{2}{|c|}{ NTA } \\
\cline { 2 - 3 } & C. flour & C. starch \\
\hline 0 & $2,74 \pm 0,05 \mathrm{a}$ & $2,74 \pm 0,06 \mathrm{a}$ \\
\hline 1 & $2,72 \pm 0,07 \mathrm{a}$ & $2,66 \pm 0,06 \mathrm{~b}$ \\
\hline 3 & $2,62 \pm 0,03 \mathrm{a}$ & $2,52 \pm 0,08 \mathrm{c}$ \\
\hline 5 & $2,46 \pm 0,13 \mathrm{a}$ & $2,62 \pm 0,11 \mathrm{bc}$ \\
\hline
\end{tabular}

Table 6 shows the solubility speed of tamarind paste at room temperature with the addition of cassava flour and cassava starch for a thickening agent. Both NTA give the same effect, adding a thickening agent adds more time to solve the paste at room temperature. The shortest time to solve the paste was the control $(67,67 \mathrm{~s})$, and the longest time to solve was for $5 \%$ addition of cassava starch (93s).
Table 6. The solubility speed (s) of tamarind paste with the addition of a NTA at room temperature.

\begin{tabular}{|c|c|c|}
\hline \multirow{2}{*}{$\begin{array}{c}\text { Concentration } \\
(\%)\end{array}$} & \multicolumn{2}{|c|}{ NTA } \\
\cline { 2 - 3 } & C. flour & C. starch \\
\hline 0 & $67,67 a$ & $67,67 a$ \\
\hline 1 & $75,33 a$ & $80,00 a$ \\
\hline 3 & $78,00 a$ & $82,67 a$ \\
\hline 5 & $83,00 a$ & $93,00 a$ \\
\hline
\end{tabular}

Thus, cassava flour has a better time to solve the paste compared with cassava starch. Several factors affect solubility speed, including temperature, solute size, solvent volume, and stirring speed [13].

\section{CONCLUSION}

The addition of a NTA showed that adding 5\% cassava starch had the best effects on the viscosity 8,586 Pa.s, water content $74 \%$, and $\mathrm{pH} 2.46$. Furthermore, cassava flour $5 \%$ gave the highest value in the solubility test, $19.33 \%$, and starch content is $3.05 \%$. Therefore, the solubility speed is slower with the addition of a thickening agent. The addition of $3 \%$ cassava starch resulted in ash content of $1.66 \%$. This study suggests that the derivative products of cassava var. Gajah, in the form of starch and flour could be used as an alternative natural thickener in the manufacture of tamarind paste.

\section{ACKNOWLEDGMENTS}

We thank to the Faculty of Agriculture, Mulawarman University, who has funded this research through a lecturer research grant as a source of non-tax revenue for the Faculty of Agriculture, Mulawarman University, in 2021.

\section{REFERENCES}

[1] Candra KP, Kasma, Ismail, Marwati, Murdianto W, Yuliani. Optimization method for bioethanol production from giant Cassava (Manihot esculenta var. Gajah) originated from East Kalimantan. Indones

[2] J Chem. 2019;19(1):176-82.De Caluwé E, Halamová K, Van Damme P.

[3] Tamarindus indica L. - A review of traditional uses, phytochemistry and pharmacology. Afrika Focus. 2010;23(1).

[4] Menezes APP, Trevisan SCC, Barbalho SM, Guiguer EL. Tamarindus indica L. A plant with multiple medicinal purposes. J Pharmacogn 
Phytochem [Internet]. 2016;5(53):50-4. Available from: http://www.phytojournal.com/archives/2016/vol5 is sue3/PartA/5-3-7-335.pdf

[5] Silalahi M. Bioaktivitas asam jawa (tamarindus indica) dan pemanfaatannya. Florea $\mathrm{j}$ biol dan pembelajarannya. 2020;7(2):85.

[6] Liu J, Xu B. A comparative study on texture, gelatinisation, retrogradation and potential food application of binary gels made from selected starches and edible gums. Food Chem [Internet]. 2019;296(January):100-8. Available from: https://doi.org/10.1016/j.foodchem.2019.05.19

[7] Komorowska P, Różańska S, Różański J. Effect of the degree of substitution on the rheology of sodium carboxymethylcellulose solutions in propylene glycol/water mixtures. Cellulose. 2017;24(10):4151-62.

[8] Pujokaroni AS, Ohtani Y, Ichiura H. Ozone treatment for improving the solubility of cellulose extracted from palm fiber. J Appl Polym Sci.2020;(January):1-11.

[9] Lidiasari E, Syafutri MI, Syaiful F. Pengaruh Perbedaan Suhu Pengeringan Tepung Tapai Ubi Kayu Terhadap Mutu Fisik dan Kimia Yang Dihasilkan. J Ilmu-Ilmu Pertan Indones. 2006;8(2):141-6.

[10] Misbah R, Muhammad A, Muhammad I, Sultan A, Rana ARK, Mohsin R, et al. Estimation of amylose, protein and moisture content stability of rice in multi locations. African $\mathrm{J}$ Agric Res. 2018;13(23):1213-9.

[11] Shittu TA, Alimi BA, Wahab B, Sanni LO, Abass AB. Cassava Flour and Starch: Processing Technology and Utilization. Tropical Roots and Tubers: Production, Processing and Technology. 2016. 415-450 p.

[12] Aini N, Purwiyatno H. Gelatinization properties of white maize starch from three varieties of corn subject to oxidized and acetylated-oxidized modification. Int Food Res J. 2010;17(4):961-8.

[13] Jackson DS, Ratnayake WA. Gelatinization and Solubility of Corn Starch during Heating in Excess Water : New Insights. J Agric Food Chem. 2006;54(1):3712-6.

[14] Tako M, Tamaki Y, Teruya T, Takeda Y. The Principles of Starch Gelatinization and Retrogradation. Food Nutr Sci. 2014;05(03):28091.

[15] Alcázar Alay SC, Meireles MAA

Physicochemical properties, modifications and applications of starches from different botanical sources. Food Sci Technol. 2015;35(2):215-36.

[16] H. Barringer, R. Kuiper, A. Pnueli, Now you may compose temporal logic specifications, in: Proceedings of the Sixteenth Annual ACM Symposium on the Theory of Computing (STOC), ACM, 1984, pp. 51-63. DOI: https://doi.org/10.1145/800057.808665

[17] Pnueli, In transition from global to modular temporal reasoning about programs, in: K.R. Apt (Ed.), Logics and Models of Concurrent Systems, Springer, Berlin, Heidelberg, 1984, pp. 123-144. DOI: https://doi.org/10.1007/978-3-642-824531_5

[18] Meyer, Applying "Design by Contract", Computer 25(10) (1992) 40-51. DOI: https://doi.org/10.1109/2.161279

[19] S. Bensalem, M. Bogza, A. Legay, T.H. Nguyen, J. Sifakis, R. Yan, Incremental component-based construction and verification using invariants, in: Proceedings of the Conference on Formal Methods in Computer Aided Design (FMCAD), IEEE Press, Piscataway, NJ, 2010, pp. 257-256.

[20] H. Barringer, C.S. Pasareanu, D. Giannakopolou, Proof rules for automated compositional verification through learning, in Proc. of the 2nd International Workshop on Specification and Verification of Component Based Systems, 2003.

[21] M.G. Bobaru, C.S. Pasareanu, D. Giannakopoulou, Automated assume-guarantee reasoning by abstraction refinement, in: A. Gupta, S. Malik (Eds.), Proceedings of the Computer Aided Verification, Springer, Berlin, Heidelberg, 2008, pp. 135-148. DOI: https://doi.org/10.1007/978-3-540-70545-1_14 